\title{
円弧歯形かさ歯車をもつ傾斜歯車減速装置*
}

\author{
長 㟢羊 一*1, 藤井 亮*1, 大西宏 征 ${ }^{* 2}$
}

\section{Reduction Gears with Inclined Planetary Gear and Arc Tooth Bevel Gear}

\author{
Yoichi NAGASAKI*3, Makoto FUJII and Hiroyuki OONISI \\ ${ }^{* 3}$ Faculty of Engineering, Kinki University, \\ 1 Takayaumenobe, Higashihiroshima-shi, Hiroshima, 739-2116 Japan
}

\begin{abstract}
We have designed new reduction gear, in which the arc tooth bevel gear is fixed on the inclined planetary gear. Making use of the shim, we can easily adjust the backlash of the reduction gear. Such basic characteristics as the noise, the torsion and the transmission efficiency of this system, with and without the backlash, are measured by changing the load torque. We find that the noise of the system under loading does not change much even when the backlash is adjusted, while the torqueangle of torsion characteristics show hysteresis loop. The transmission efficiency of the system without the backlash is appreciably lower than that with the backlash for the low load torque. As the applied load torque is increased further, the transmission efficiency of the system increases, and the efficiency without the backlash approaches to the transmission efficiency of the system with the backlash.
\end{abstract}

Key Words: Gear, Circular Arc Tooth Profile, Bevel Gear, Inclined Planetary Gear, Reduction Gear, Tooth Bearing, Torsional Rigidity, Backlash, Noise Level, Efficiency

\section{1. 踷言}

傾斜歯車减速装置（偏心差動歯車装置）は，入力軸 に対して僅かに軸角をもつ傾斜歯車 (遊星歯車) が固 定歯車および出力歯車にかみ合っている特殊な機構を もっている. 傾斜歯車减速装置に関する研究は, 数例 報告されている(1)〜(4). これらの研究において，一つは (1) (3)，一般転位内歯車，一般転位円寸い形内歯車とク ラウニングを施したピニオンをかみ合わせた傾斜歯車 減速機を設計，試作し，この减速機は実用に供し得る ものと述べている. しかしながら，歯形加工はかなり 複雑で容易ではないと考えられる. 他の一つは ${ }^{(4)}$, 円 弧歯形で, 外歯車 (かさ歯車に似た円すい台形) 同士 のかみ合う試作機の効率, 騒音などについて述べたも のである.この傾斜歯車减速装置 (偏心差動歯車装置) (4)において，かみ合う歯車の歯形は，一方では半円筒 状の凸円弧歯, もう一方では半円溝状の凹円弧歯であ る. また，凸円弧歯には円筒ピンを使用している.こ

* 原稿受付 2006 年 3 月 31 日.

*1 正員, 近畿大学工学部(画739-2116 東広島市高屋うめの辺 1).

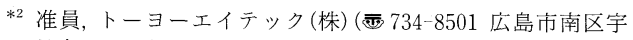
品東 5-3-38)

E-mail : nagasaki@ hiro.kindai.ac.jp
れらの歯形をもつ歯車が，入力軸に対して僅かに傾斜 し，かみ合っている.このような構造をもつこの装置 では, 構成する部品の寸法精度やそれらの組み付け精 度によってその性能に影響を受けると考えられる. そ のため, 本装置では軸方向に傾斜歯車を移動すること によって，歯車間の歯面間距離を変えて，かみ合い円 周力の方向のバックラッシを調整することができ，な くすことも可能となっている. 将来, この装置が各種 ロボット, 各種位置決め装置などの精密さと信頼性が 求められる幅広い範囲で利用される減速機になると思 われる.しかしながら，この装置では，外歯車同士を かみ合わせるという構造になり，かみ合いに基づく創 成円弧歯形を用いる必要が生じる. このため歯形の加 工が複雑になり, 特殊な歯形加工機を必要とする. し たがって, 本研究では, エンドミルを使いマシニング センターでも容易に加工できる凹円弧歯を用い，新た に円弧歯形かさ歯車をも八傾斜歯車減速装置を設計し 試作を行った.この円弧歯形かさ歯車はピッチ円すい 角のかなり大きいすぐばかさ歯車と考えられ, 歯形は ピッチ円を中心とする円弧である. したがって, 歯形 の中心がピッチ点にくると接触により力を伝える歯車 である. 凹円弧歯の曲率半径は凸円弧歯に比べて僅か 
に大きくなっている．この試作减速装置を用い，かみ 合い円周力の方向のバックラッシを有無にし，㸚じり 剛性，騒音および効率を明らかにすることができたの で報告する。

\section{2. 実酸条件}

$2 \cdot 1$ 頃斜歯車娍速装置 図 1 亿傾斜歯車减速装置 の構造を示す。この装置は原理的には，一般の $2 \mathrm{~K}-\mathrm{H}$ 型差動歯車装置と同様に遊星歯車 (歯数が僅かに違う) 間の速度差を利用するものである．相違する点は，本 装置の場合, 図 1 の上うに傾斜歯車(2), (3)の回転軸が 入力軸に対して僅かに傾いており，傾斜歯車(2),(3) 入力軸の回転と共に，すりこぎ運動をしながら固定歯 車(1), 出力歯車(4)とか夕合って動力を伝澾する.

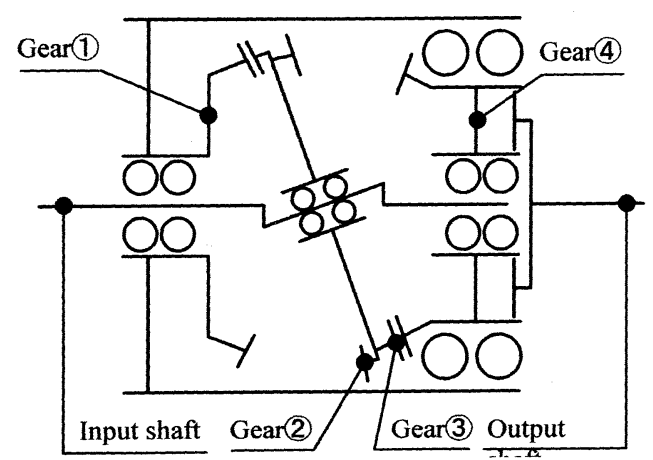

Fig.1 Construction of gear system with inclined planet

2.1.1 速比（U） 図2に示すように, $r_{1}, Z_{1}$ を 固定歯車(1)， $\mathrm{r}_{2}, \mathrm{Z}_{2}$ を傾斜歯車(2)， $\mathrm{r}_{3}, \mathrm{Z}_{3}$ を傾斜歯車(3), $\mathrm{r}_{4}, \mathrm{Z}_{4}$ を出力歯車(4)のそれぞれの歯幅中央でのピッチ 円半径と蒾数とし，また入出力軸と傾斜軸とのなす角 (軸角) を $\theta$ とし, 固定歯車(1)と出力歯車(4)の間の長

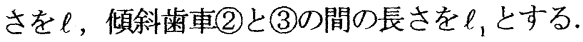

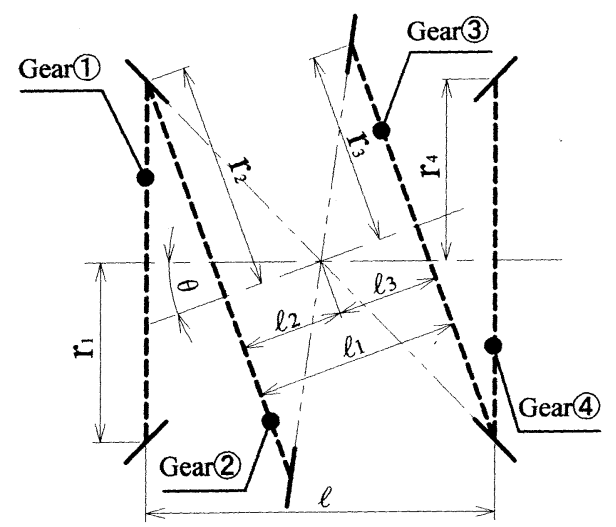

Fig.2 Dimensions of gear system with inclined planet gear
本装置の場合，速比 $u$ は同型の差動歯車装置と同様に なり，次式のように表わされる.

$$
\begin{aligned}
& u=1-\frac{Z_{1} Z_{3}}{Z_{2} Z_{4}} \\
&=1-i_{0} \\
& \text { ただし, } i_{0}=\frac{Z_{1} Z_{3}}{Z_{2} Z_{4}}
\end{aligned}
$$

傾斜軸と出力軸が同一回転方向の場合は，

$$
Z_{2} Z_{4}>Z_{1} Z_{3}
$$

逆回転方向の場合は,

$$
Z_{2} Z_{4}<Z_{1} Z_{3}
$$

が成り立ち, 次式の場合は, 速比 $u=0$ となり, 動力を 伝達することはできない．

$$
Z_{2} Z_{4}=Z_{1} Z_{3}
$$

$2 \cdot 1 \cdot 2$ 項斜歯車減速装置の寸法 図 2 より, 固定 歯車(1)と出力歯車(4)との間の長さ $\ell$ は次式のようにな る.

$$
\ell=\frac{r_{2}+r_{3}-\left(r_{1}+r_{4}\right) \cos \theta}{\sin \theta}
$$

また，傾斜歯車間の長さは次式のようになる.

$$
\ell_{1}=\frac{\left(r_{2}+r_{3}\right) \cos \theta-\left(r_{1}+r_{4}\right)}{\sin \theta}
$$

式（6）において, $r_{1}+r_{4}=A, r_{2}+r_{3}=B$ とおくと,

$$
B \cos \theta=A+\ell_{1} \sin \theta
$$

式（7）の両辺を二乗し， $\theta$ を求める.ここで， $\theta$ は $0^{\circ}<\theta<90^{\circ}$ なので,

$$
\theta=\sin ^{-1}\left(\frac{-A \ell_{1}+B \sqrt{B^{2}+\ell_{1}{ }^{2}-A^{2}}}{B^{2}+\ell_{1}{ }^{2}}\right)
$$


これらの式は，円弧歯形かさ歯車をもつ傾斜歯車减速 装置の寸法や軸角などを決定する基本式となる. 各歯 車対のモジュールを $m=1.4$, 各歯車の歯数を, 固定・ した場合の, 軸角 $\theta$ と固定・出力歯車間の長さ $\ell$ との 関係を図 3 に示寸。この図より, 軸角 $\theta$ が 3 ○よりさ くなると急激に固定・出力歯車間の長さ $\ell$ が長くなり,

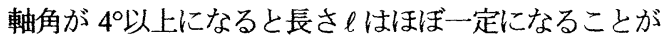
わかる. したがって, 本装置の小型化には軸角 $\theta$ が重 要であることがわかり, 本装置では軸角 $\theta$ を $6^{\circ}$ とした.

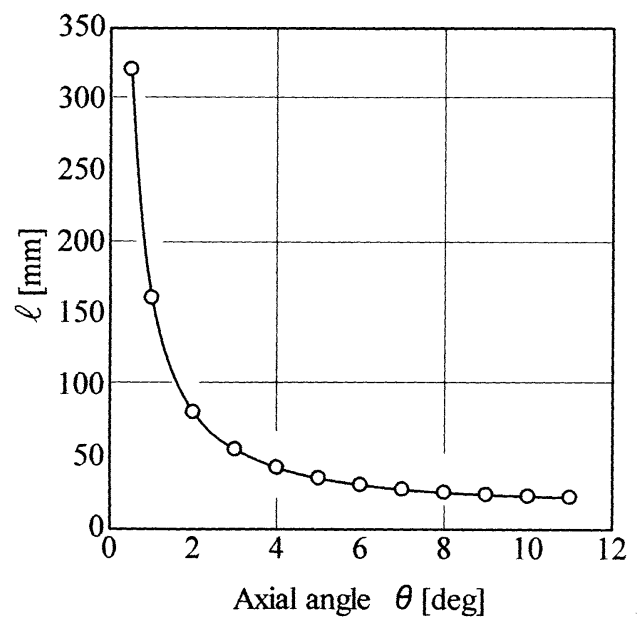

Fig.3 Length from Gear(1) to Gear(4) 出力歯車 $Z_{1}=Z_{4}=57$, 傾斜歯車 $Z_{2}=60, Z_{3}=58$ と

\section{$2 \cdot 2$ 円弧歯形かさ歯車をもつ幁斜歯車娍速装置の}

試作 試作减速装置の設計仕様は, 伝達動力 $200 \mathrm{~W}$, 定格トルク $29.4 \mathrm{~N} \cdot \mathrm{m}$, 入力回転数 $1800 \mathrm{rpm}$, 减速比 30 とした. 出力軸の回転方向は入力軸回転方向之同方向 である. 図 4 は試作した円弧歯形かさ歯車をもつ傾斜

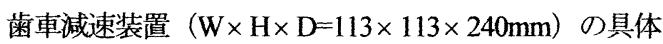
的な組立図であり，表 1 亿試作减速装置の歯車要目を 示す. (1)は入力側固定ピン歯形かさ歯車，(2),(3)は傾斜 円弧歯形内かさ歯車, (4)は出力側ピン菌形かさ歯車, (5)は入力軸，(6) は入力軸支持のケーシング，(7)は出力 支持のケーシング，(8)は出力側ケーシング，(9)は出力 軸である. 傾斜円弧㐘形内かさ歯車の材質は SUJ2 と し，無酸化焼入れで処理してある.

Table 1 Specification of test gears

\begin{tabular}{|c|c|c|c|c|}
\hline & Fixed gear & \multicolumn{2}{|c|}{ Inclined planet gear } & \multirow{2}{*}{ Gear 4 } \\
\cline { 2 - 4 } & Gear 2 & Gear 3 & \\
\hline $\begin{array}{c}\text { Circular arc tooth } \\
\text { profile }\end{array}$ & Convex & Concave & Concave & Convex \\
\hline $\begin{array}{c}\text { Module (radius of } \\
\text { circular arc) }\end{array}$ & $1.4(1.25)$ & $1.4(1.25)$ & $1.4(1.25)$ & $1.4(1.25)$ \\
\hline $\begin{array}{c}\text { Number of teeth } \\
\text { Angle of Inclination }\end{array}$ & $\mathrm{Z}_{1}=57$ & $\mathrm{Z}_{2}=60$ & $\mathrm{Z}_{3}=58$ & $\mathrm{Z}_{4}=57$ \\
\hline Face width [mm] & 7.0 & 6.0 & 6.0 & 0 \\
\hline Material & 6.0 & 6.0 & 7.0 \\
\hline Heat treatment & \multicolumn{4}{|c|}{ SUJ2 } \\
\hline Surface finishing & \multicolumn{3}{|c|}{ Anoxia-hardening } & \\
\hline
\end{tabular}

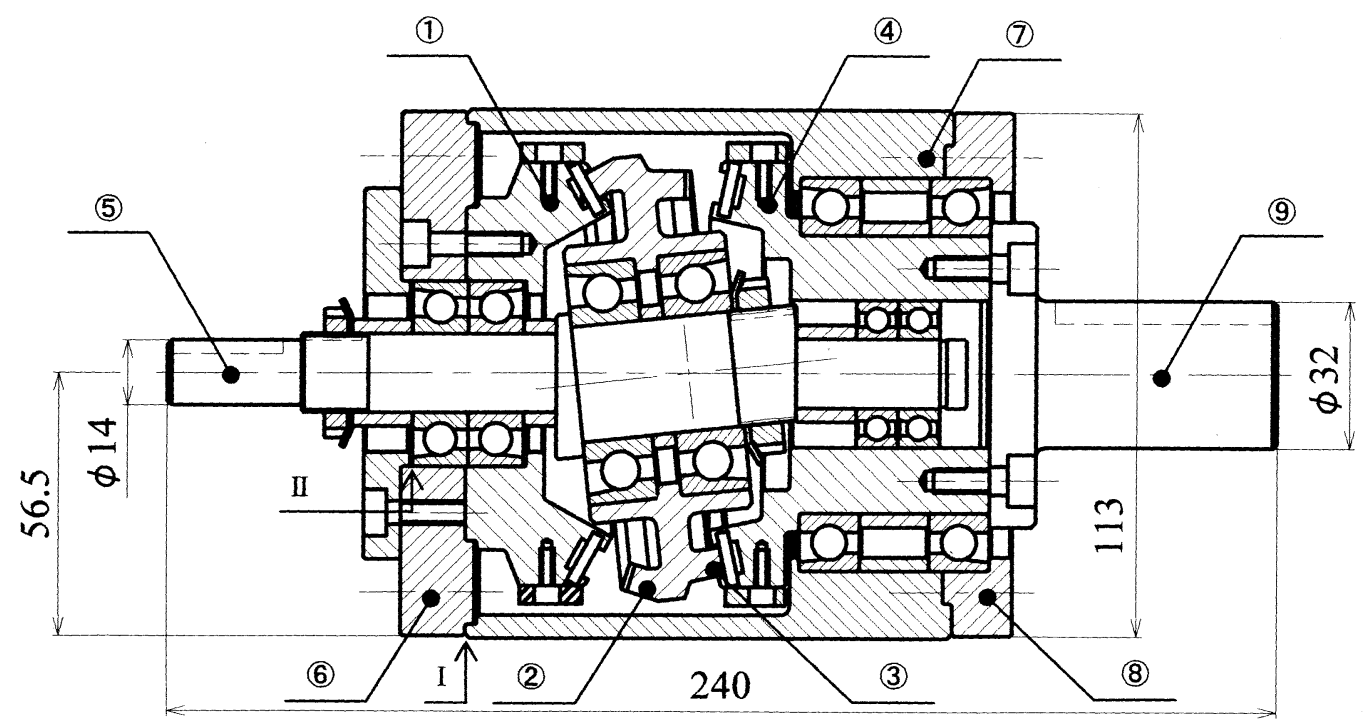

Fig.4 Concrete assembly figure of gear system with inclined planet gear 
2-2:1 歯形 図 5 に固定歯車(1)と傾斜歯車のか夕 合いを示し, 図 6 に各歯車の歯形を示す. 入力側固定 ピン歯形かさ歯車(1)および出力側ピン歯形かさ歯車(4) の歯は, 軸受用の二ードル（直径 $2.5 \mathrm{~mm}$, 径方向公差 h6, 長さ $11.8 \mathrm{~mm}$ ) の両端を円筒支持した図 6 (a) に 示寸ような凸円弧歯（半円筒状）であり，傾斜円弧歯 形内かさ歯車(2),(3)は図6(b) に示すような凹円弧歯 (半 円状の溝) である.

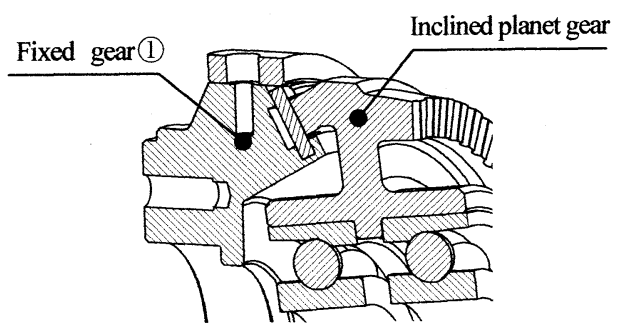

Fig.5 Meshing between fixed gear(1), gear(4) and inclined planet gear(2),(3)

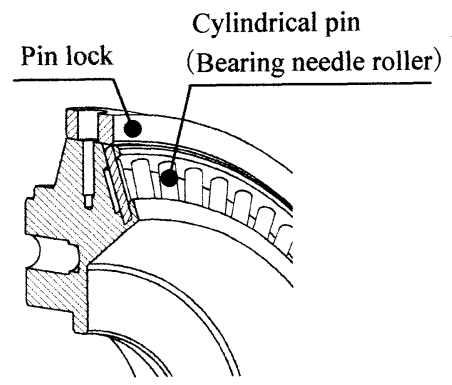

(a) Fixed gear(1) and gear(4)
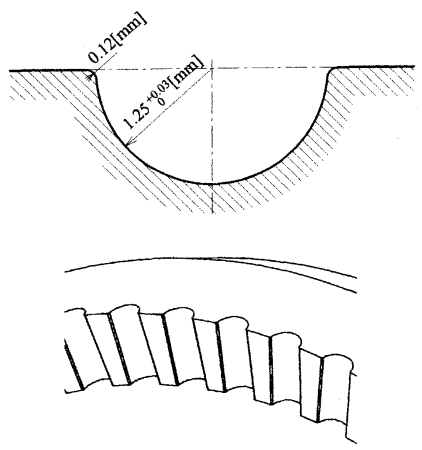

(b) Inclined planet gear(2),(3)

Fig.6 Tooth profile

図 7 に入力側の傾斜歯車の歯当たりを示す. 出力側も ほぼ同様な歯当たりであった，歯当たり試験は，歯面 に光明丹を塗って，無負荷で歯車を手動で回転させて 行った.この図より, どの軸方向移動量タイプも歯先 部分で，歯すじ方向にほぼ一様に接触しており，また 接触幅は, 歯面押付け力の大きい軸方向移動量Aタイ
プの場合が他のタイプに比べて，僅かに大きくなって いるのがわかる.

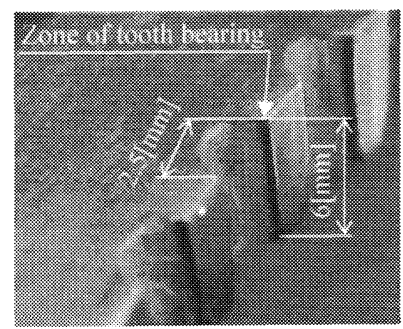

(a) A Type

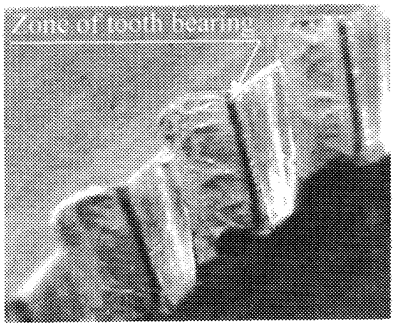

(b) B Type

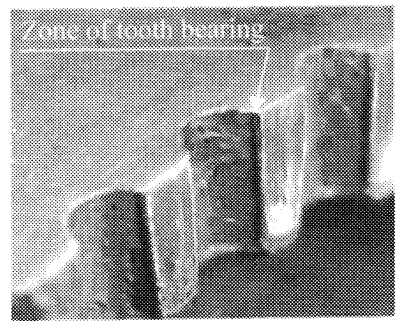

(c) C Type

Fig.7 Tooth bearing of planet gear(2)

$2 \cdot 3$ 実験装置と実験方法 傾斜歯車の軸方向移動 量（精度 $0.1 \mathrm{~mm}$ ）を変化させながらねじり予備試験を 行った.ねじり試験結果より入出力歯車詨のかみ合い 円周力の向のバックラッシ（以後, 単にバックラッ シ）がなくなる位置を求めた，本装置では，傾斜歯車 を軸方向に移動させることで，入出力側の歯車対の歯 面間距離を変化させることができる．予備実験の方法 は, 図4の I , II 部に真鍮製のシムを挿入し，傾斜歯車 を軸方向に移動させたＩ部へのシムの挿入は歯車(3), (4)間，I部へのシムの挿入は歯車(1),(2)間の歯面間距離 を調整できる. 入出力側歯車対のバックラッシがなく なる状態を A タイプ，これを基準とし，その後，バッ クラッシが生じる方へ傾斜歯車を軸方向に移動した. 傾斜歯車の軸方向移動量を, 表 2 のように 3 タイプと した. A タイプが入出力側歯車対のバックラッシのな くなる，すなわち歯面を押付ける力が大きくなる状態 である. 
Table 2 Thickness of shim

\begin{tabular}{|c|c|c|}
\hline Type & I part & II part \\
\hline A & $0[\mathrm{~mm}]$ & $0[\mathrm{~mm}]$ \\
\hline B & $0.8[\mathrm{~mm}]$ & $0.2[\mathrm{~mm}]$ \\
\hline C & $1.1[\mathrm{~mm}]$ & $0.6[\mathrm{~mm}]$ \\
\hline
\end{tabular}

ねじり岡性，騒音および効率の実験は，予備実験によ り決定した 3 タイプの軸方向移動量で行った. ねじり 試験は図 8 のように入力軸に天秤を取り付け，出力軸 を固定し, 天秤に錘を $0.01 \mathrm{~N}$ づつ載せて, 天秤の傾き $\gamma$ と負荷トルク（入力トルクと速比より計算）から，ね じり特性を求めたねび゙り試験方法は片側の錘を徐々 に大きくし，天秤の腕上の位置（入力軸中心からの長 さ $\left.L_{a}\right)$ での垂直方向変位 $H_{a}$ をスケールをあてて測定 した.

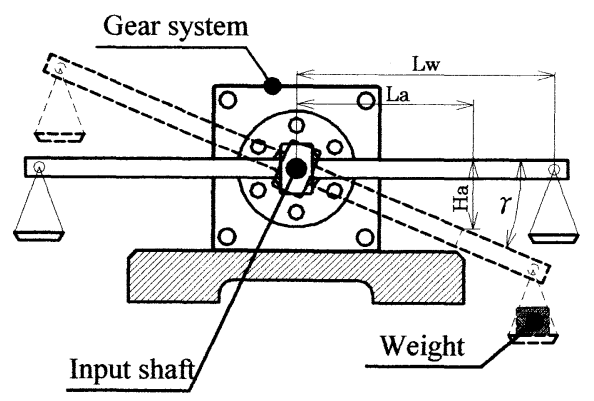

Fig.8 Measuring method of torsion

図 8 より, $L_{W}$ に比べ天秤の腕の断面が十分小さい時, 回転角 $\gamma$ は次式のようになる.

$$
\gamma=\sin ^{-1} \frac{H_{a}}{L_{a}}
$$

そのときに要したトルク $T$ は, 錘の重さを $W$, 水平時 の中心から錘までの距離を $L_{W}$ とすると, 図 8 より, 次式のようになる.

$$
T=W \cdot L_{W} \cdot \cos \gamma
$$

図 9 に歯車試験機を示す. 本実験では動力吸収式の試 験機を用いた. 動力として $400 \mathrm{~W}, 4$ 極, 1800rpm の3 相インダクションモータを使用し, 負荷トルクは電磁 パウダーブレーキでかけることができる. また, 傾斜 歯車减速装置の入力軸および出力軸に, それぞれトル クメータを取り付けている. 傾斜歯車の潤滑にはグリ 一ス（L74V）を使用した. 本実験では, 負荷トルクは $9.8,19.6,29.4 \mathrm{~N} \cdot \mathrm{m}$, 傾斜歯車の軸方向移動量を表 2 の
$\mathrm{A}, \mathrm{B}, \mathrm{C}$ タイプとして, 入力軸側の回転数を $1800 \mathrm{rpm}$ で一定とし，無負荷状態でならし運転を 1 時間行った 後, 運転時間を 3 時間とし, 傾斜歯車減速装置の入出 力軸のトルクおよひ騒音を測定した. 測定は数回行い, 再現性を確かめた. 本論文で使用しているトルク, 騒 音の数值は実験値の平均值である.

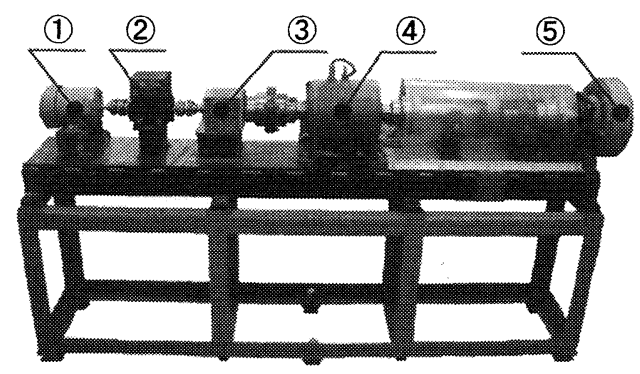

\begin{tabular}{|l||l|}
\hline (1) & Motor \\
\hline (2) & Torquemeter (Input side) \\
\hline (3) & Gear system with inclined planet gear \\
\hline (4) & Torquemeter (Output side) \\
\hline (5) & Magnetic brake \\
\hline
\end{tabular}

Fig.9 Schematic view of gear testing machine

\section{3. 実験結果と考察}

3・1 ねじり特性 図 10 に本実験に用いた傾斜歯車 減速装置のねじり試験の結果を示す。この図に軸方向 移動量各タイプについて、横軸に負荷トルク，縌軸に ねじり角をとり，両者の関係を示した.この線図にお いて，段差が生じたのは，天秤に手で錘を載せている ため, 同じ状態で連続的に錘を載せられないことによ るものと考えられる. 軸方向移動量に関係せず，負荷 トルクが小さい場合, 負荷トルクとねじり角の関係は ほぼ比例関係にあるが，負荷トルクの増加にともなっ てねじり角の増加の割合が小さくなっており, 非線形 の硬化性ばね特性を示している．また，軸方向移動量 A タイプは予圧形歯車装置にみられるヒステリシスル 一プを描き, バックラッシの存在を示すトルク $0 \mathrm{~N} \cdot \mathrm{m}$ 付近に生じる急激なねじり角の変化がないことから, バックラッシはない. しかし，バックラッシはB タイ プでは少し，Cタイプではかなりある.このように, 本装置ではバックラッシをなくすことが可能である. 軸方向移動量が A, B , C タイプと変化するとねじり角 も増加することがわかる.これは, 軸方向移動量の増 加とともに, 軸方向移動により発生する歯面荷重が小 さくなると考えられる. また, 低負荷トルクの場合, ねじり角の変化が大きいことがわかる. 


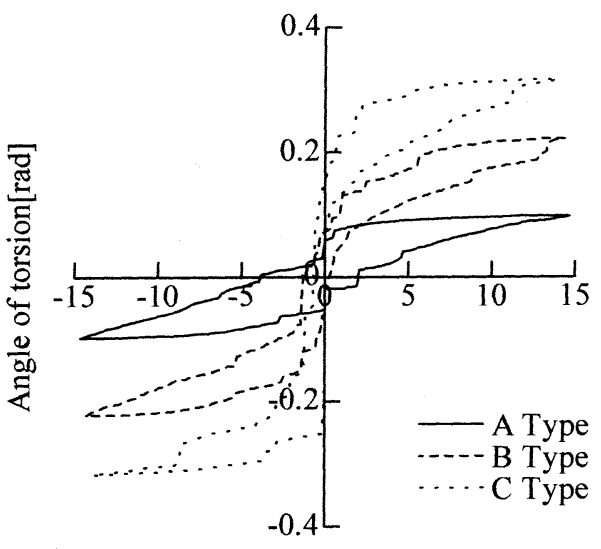

Torque[N·m]

Fig.10 Torque - angle of torsion characteristic

3-2 路音特性 騷音レベルは, 精密騒音計を用い, 本装置の側面より $1 \mathrm{~m}$ の位置で周波数特性を A 特性で 測定した. また，その出力を FFT 周波数分析装置によ り，騒音の周波数分析も行った. 暗騒音の影響は指示 の差が $10 \mathrm{~dB}$ 以上なので影響を受けないとした．無負 荷時で，各軸方向移動量夕イプに対する騒音の周波数 分析結果を 図 11 に示す.この図より本装置の主な騒 音成分は歯のかみ合い周波数を $f_{Z}$ とすると， $f_{Z}, 2 / 3 f_{Z}, 5 / 3 f_{Z}$ などが現れていることがわかる. 他 の負荷トルクの場合もほぼ同様な騒音成分の結果であ った. 図 12 に負荷トルクと騒音レベルおよび軸方向移 動量との関係を示す．騒音レベルは，バックラッシの ある場合，すなわち軸方向移動量 C タイプの場合は, 負荷トルクの増加とともに急に増加し，しだいに増加 の割合が減じ，飽和する．バックラッシのない軸方向 移動量 A タイプ, バックラッシの少しある B タイプの 騷音レベルは負荷トルクを増加させても僅かに増加 するか，あるいはほとんど変化がない．これらの 原因としては，歯面荷重およびねじり戌性の影響が 考えられる. すなわち, バックラッシのあるC タイプ の場合，低負荷トルク時，軸方向移動によって発生す る歯面荷重は小さく, ねじり剛性も低いので, 各歯車 のかみ合いによる振動は小さい，また負荷トルクの増 加（歯面荷重の増加）によって，ねじり剛性も増加 する. しかし負荷トルク（歯面荷重）の増加割合に比 ぶて, ねじり剛性の増加の割合は低くなっている. し たがって，これらの影響が各歯車のかみ合いによる振 動に現れ, 騒音レベルは図 12 の軸方向移動量Cタイプ のようになる. バックラッシのないあるいは少ない場 合，低負荷トルク時，ねじり剛性はバックラッシのあ る場合に比べて高く，軸方向移動によって発生する歯
面荷重が大きくなる．また前述のように，負荷トルク (歯面荷重) が増加しても, ねじり剛性の増加の割合 は低くなっている.これらが各歯車のかみ合いによる 振動に現れ，騒音レベルは図 12 の軸方向移動量 A,B タイプのようになる.

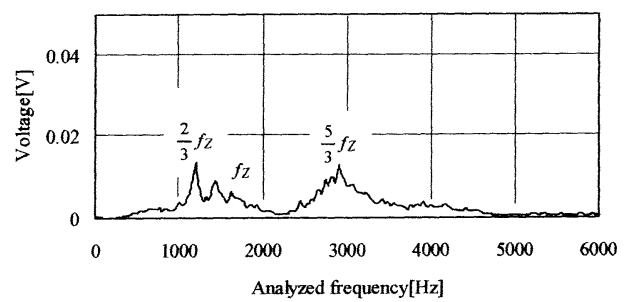

(a) A Type

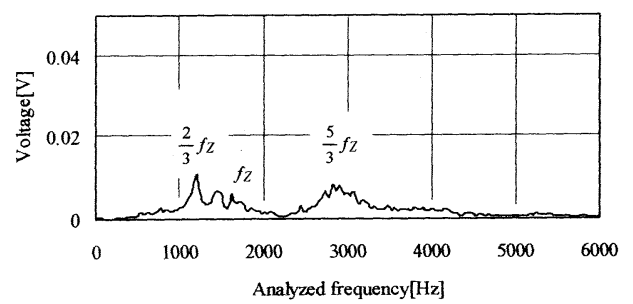

(b) B Type

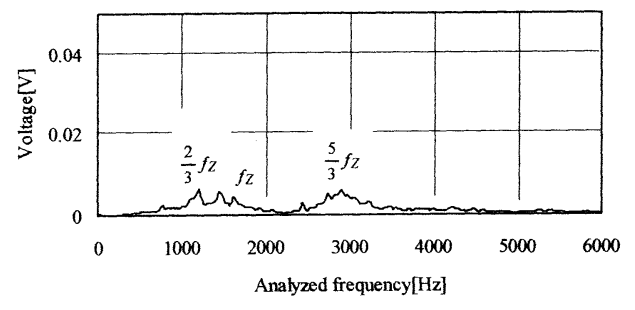

(c) C Type

Fig.11 Frequency analysis of gear system noise

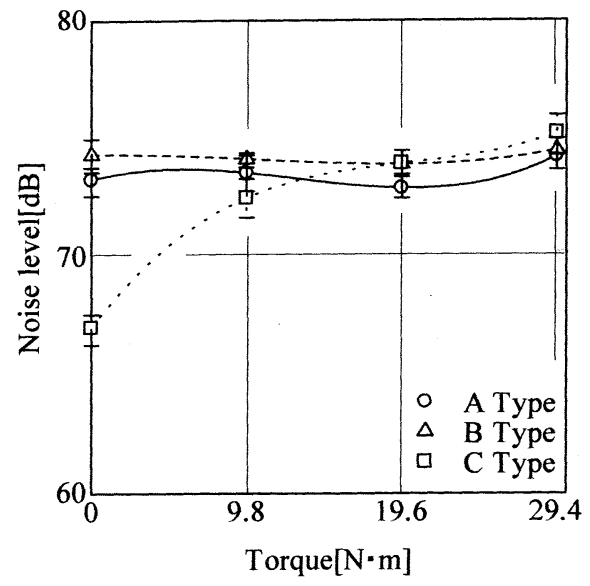

Fig.12 Noise of gear system 
3-3 効率特性 効率 $\eta$ は入力軸側トルク $T_{1}$, 出力軸側トルク $T_{2}$ および前述の速比 $u=1 / 30$ から, $\eta=T_{2} /\left(30 T_{1}\right)$ と計算できる. 図 13 に本装置の損失 トルクと軸方向移動量タイプとの関係を示す.こ の図より，本装置の損失トルクはAタイプが大き く, 次にCタイプで, Bタイプが 1 番小さくなっ ている. 図 14 に負荷トルクと効率および軸方向移 動量タイプとの関係を示す. 各タイプの軸方向移 動量に関係なく効率は負荷トルクの増加に伴い増 加する. 負荷トルク $9.8 \mathrm{~N} \cdot \mathrm{m}$ において, 軸方向移動 量 $\mathrm{B}$ タイプの効率が高く, 軸方向移動量 $\mathrm{A}$ タイプ の効率が極端に低いことがわかる。これは，軸方 向移動量 A タイプでは, 軸移動により発生する歯 面荷重, 歯当たりおよびピン（ニードル）の長手 方向の速度差の違いによって生じるかみ合い面上 での摩擦係数による負荷トルク（装置自身の損失 トルク）の影響を受けて，効率が減少したと考え られる. 負荷トルク $29.4 \mathrm{~N} \cdot \mathrm{m}$ では, 負荷トルク $9.8 \mathrm{~N} \cdot \mathrm{m}$ 時に比べて各タイプの軸方向移動量におけ

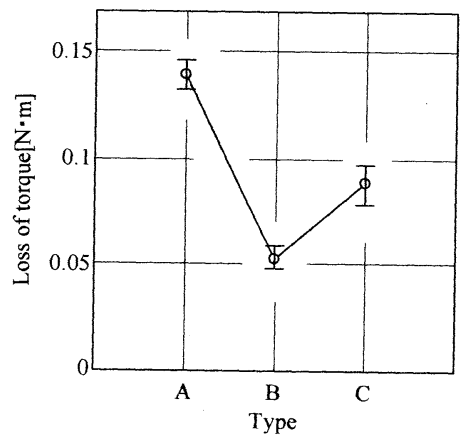

Fig.13 Loss torque of gear system

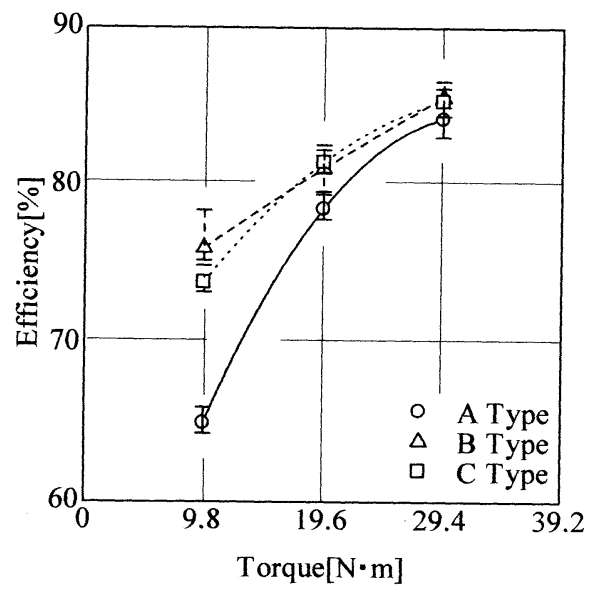

Fig.14 Efficiency of gear system
る効率の值が近づいていることがわかる。これは 負荷トルクが増大すると, 各タイプの軸方向移動 によって発生する歯面荷重および歯当たりにもと づく負荷トルク（装置自身の損失トルク）の影響 が小さくなったためだと考えられる. 負荷トルク $29.4 \mathrm{~N} \cdot \mathrm{m}$ 時に各タイプの軸方向移動量において効 率の值が最大值を示した。軸方向移動量 $\mathrm{A}$ タイプ では 84.26\%, B タイプでは 85.64\%,Cタイプでは 85.38\%であり，大きな差は生じていない．また負 荷トルクの増加にともない各タイプの軸方向移動 量における効率の值が近づいていくことがわかる。

\section{4. 結言}

円弧歯形かさ歯車をもつ傾斜歯車减速装置の特徴を 述べ，さらに装置の試作機を使用し，か夕合い円周力 の方向のバックラッシを有無にするため, 歯面間距離 を変化させてねじり試験および運転試験を行い, ねじ り特性, 騒音および効率について測定し, 考察を行っ た結果, 以下の結論を得た.

（1）本装置は、歯車加工が容易であり，また歯面間の 距離を変えることによりバックラッシをなくす ことができる.

（2）本装置の騒音レベルはバックラッシがないあるい は少ない場合, 負荷トルクが変化してもほとんど 変わらない. ただし，バックラッシがある場合， 騷音レベルは負荷トルクの大小によって変わる.

（3）本装置の効率はバックラッシがない場合, バック ラッシのある場合に比べて, 低負荷トルクでは低 いが，高負荷トルクになるにしたがって高くなり， 両方の場合の效率は近づき， $85 \%$ 前後を示した.

\section{5. 参考文献}

(1) Yaejima , K. and Morozumi , M., Reduction Gear System with Inclined Pinion (1st Report, Theoretical Analysis), Transactions of the Japan Society of Mechanical Engineers, Series C, Vol.60,No.572,(1994),pp.1409-1414.

(2) Yaejima , K. and Morozumi , M., Reduction Gear System with Inclined Pinion (2nd Report, Optimal Designing System), Transactions of the Japan Society of Mechanical Engineers, Series C, Vol.60,No.572, (1994),pp.1415-1421.

(3) Yaejima , K. and Morozumi , M., Reduction Gear System with Inclined Pinion (3rd Report, Trial Construction and Evaluation of Performance), Transactions of the Japan Society of Mechanical Engineers, Series C, Vol.60,No.572,(1994),pp.1422-1425.

(4)Fujii , M. and Tanaka, T., Study on Gear System with Inclined Planet Gear and Circular Arc Tooth Profile, Proceedings of Chugoku-shikoku and Kyusyu Branch Regular Meeting of the Japan Society of Mechanical Engineers, No.985-2(1998-10) ,pp.91-92. 